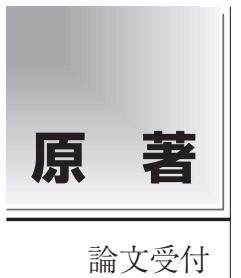

2014 年 11 月 19 日

論文受理

2015 年 1 月 10 日

Code No. 431

\section{コバルト 60 定位手術的照射装置における 線源位置変位が線量および線量分布に及ぼす影響}

\author{
中澤寿人 内山幸男
}

名古屋共立病院名古屋放射線外科センター

\section{緒 言}

頭蓋内病巣に対するガンマナイフ治療は金属製の Leksell stereotactic skull frame (ELEKTA, Sweden) を頭蓋骨に固定する方法あるいはプラスチック製のマ ウスピース式固定具 Extend frame (ELEKTA, Sweden) とバキュームクッションで固定する方法があ り， ${ }^{60} \mathrm{Co}$ 線源から放射される $\gamma$ 線をコリメータで細い ビームに収束させ, 照射する ${ }^{1)}$. 近年, ガンマナイフ 治療装置は大幅に改良され，他の放射線治療装置と同 様にコンピュータ制御による治療効率の向上が図られ ている ${ }^{2 \sim 4)}$. 従来のガンマナイフ Model B および C (ELEKTA, Sweden)では線源とコリメータが装置内 部に固定されており, 寝台の頭尾方向の移動と遮蔽扉 の開閉で照射のオンとオフを切り替えるシンプルな構
造であった ${ }^{5)}$ 。一方, 最新のガンマナイフ Perfexion (ELEKTA, Sweden)では固定されたコリメータの上 を線源自身が選択したコリメー夕位置まで移動し照射 するため ${ }^{1 \sim 4)}$, 線源移動の正確な位置制御が要求され る.この線源制御の機構は直線加速器のマルチリーフ コリメータ (multileaf collimator: MLC)の位置制御と 類似しており, 高い精度が要求される. MLCの位置 精度は特に強度変調放射線治療 (intensity modulated radiation therapy: IMRT) の際に重要で，物理的およ び臨床的な側面から検討されている ${ }^{6 \sim 11)}$. また, 日本 放射線腫瘍学会の IMRT 物理技術ガイドライン ${ }^{12)}$ で はIMRTの質を担保するために, MLC の動作性能の 確認が必要とされている。一方, Perfexionの線源移 動の精度に関する検討はこれまでに報告されておら

\title{
Effect of Source Positional Discrepancy on Dose and Dose Distributions in Cobalt-60 Stereotactic Radiosurgery Units
}

\author{
Hisato Nakazawa* and Yukio Uchiyama \\ Nagoya Radiosurgery Center, Nagoya Kyoritsu Hospital
}

Received November 19, 2014; Revision accepted January 10, 2015

Code No. 431

\section{Summary}

We assessed the impact of source positional discrepancy on dose and dose distributions in Gamma Knife (GK) Perfexion (PFX) stereotactic radiosurgery. A spherical phantom dedicated in GK machine was used and irradiated by $2 \mathrm{~Gy}$ in each position moved at an interval of $0.1 \mathrm{~mm}$ from its original position using three types of collimators $(4,8,16 \mathrm{~mm})$ to evaluate the changes of dose. In addition, to obtain the dose distributions, radiochromic film was inserted in the phantom and irradiated by $6 \mathrm{~Gy}$ in each position moved at an interval of $1 \mathrm{~mm}$ from its original position using three types of collimators. A distance-to-agreement analysis (DTA) was performed to compare isodose lines from $10 \%$ to $90 \%$ of dose distributions between the original and deviated position. As a result, when the source moved toward the discrepancy from the center of the collimator, the dose and dose distributions discrepancies increased according to the degree of discrepancy. Especially in 4-mm collimator, $0.5 \mathrm{~mm}$ discrepancy caused dose reduction of 5\%. On the other hand, $0.5 \mathrm{~mm}$ discrepancy showed merely dose differences less than $0.5 \%$ in $8 \mathrm{~mm}$ and $16 \mathrm{~mm}$ collimators. Regarding dose distributions, $1 \mathrm{~mm}$ discrepancy in all collimators showed little changes in DTA within $1 \mathrm{~mm}$ on average.

Key words: stereotactic radiosurgery, gamma knife, perfexion, dose distributions, quality assurance

*Proceeding author 
ず，国内に物理技術ガイドラインもない，そのため， ベンダの定期点検の簡易確認に依存しており，ユーザ による装置の品質管理として十分ではない，本検討で は，ガンマナイフ Perfexionに扔ける線源位置変位が 線量と線量分布に及ぼす影響をファントムで評価した。

\section{1. 対象・方法}

\section{1-1 使用機器}

定位放射線治療用装置は ELEKTA 社製ガンマナイ フ Perfexionを使用した。治療計画装置はELEKTA 社製 Leksell GammaPlan(LGP) ver. 10.1.1を使用した。 水等価ファントムは ELEKTA 社製のポリスチレン球 形ファントム (直径：16 cm) を使用し, 専用の固定具 で寝台にファントムを固定した(Fig. 1)。ファントム 中央には線量計あるいはフィルムを挿入可能な構造を もち, 専用の線量計フォルダとフィルムホルダを配置 できる。ラジオクロミックフィルムはベリタス社製の ガフクロミック EBT3, フィルムスキャナはエプソン 社製の ES-10000G，フィルム解析装置は R-tech 社製 の DD-system (DD-Analysis ver. 10.10, DD-IMRT ver. 10.12)を使用した。線量計としてセミフレックス形電 離箱の PTW 社製 PTW31010 シリアル番号 $(\mathrm{S} / \mathrm{N})$ 4012 (有感体積: 外径 $7.2 \mathrm{~mm}$, 内径 $6.5 \mathrm{~mm}$, 厚さ 7.2 $\mathrm{mm}$ ) および半導体検出器の SCANDITRONIX WELLHOFER 社製 EDD5-3G シリアル番号 $(\mathrm{S} / \mathrm{N})$ DEC612-2195(有感体積 : $\phi 1.6 \mathrm{~mm}$, 厚さ $0.08 \mathrm{~mm}$ ) を 使用し，その際に電位計は東洋メディック社製 RAMTEC Smartを使用した。

\section{1-2 ガンマナイフ Perfexion}

Perfexion は 192 本の $\gamma$ 線を直径が $4,8,16 \mathrm{~mm} の$ 3 種類の円筒型コリメータで収束させる。手前から 8 $\mathrm{mm}, 4 \mathrm{~mm}, 16 \mathrm{~mm}$ のコリメータをもつコリメータボ デイが装置に内蔵され (Fig. 2), 線源の入ったペレッ 卜容器を配置したセクタがコリメータ上を頭尾方向に 移動し、コリメータサイズを選択する(セクタは前後, 左右方向には移動しない)，更にコリメータは八つの 区域に分けられ(1 区域 24 本の $\gamma$ 線)，区域ごとにコリ メータサイズを選択(遮蔽も可能)し，1 度の照射で異 なるコリメータサイズを組み合わせる事(コンポジッ トショット)ができる (Fig. 3)。患者位置合わせ装置 (patient positioning system: PPS) ${ }^{2,3,13)}$ は寝台が照射位 置まで直接移動する仕組みをもち，患者頭部を一定の 位置で固定したまま治療可能である。金属製の頭蓋固 定枠またはプラスチック製のマウスピース式固定具で 患者を固定するため位置ズレはなく, PPS に患者を固

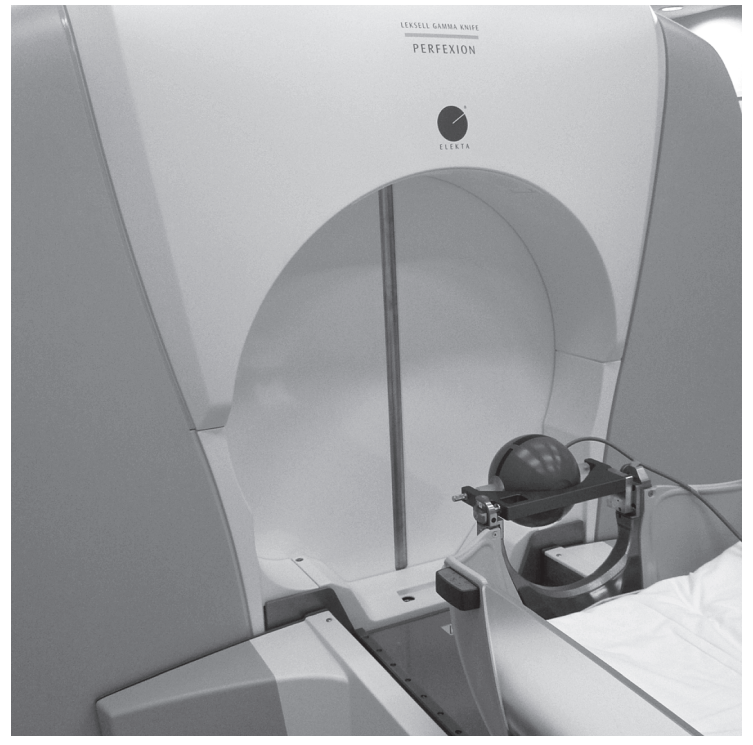

Fig. 1 Gamma Knife Perfexion and spherical phantom.

定した後に(セットアップ確認などは特に行わずに)治 療を開始する，治療座標を装置の焦点位置に合わせる ために寝台が移動した後に, 線源が選択したコリメー タサイズの位置まで移動し，照射が開始する，治療計 画で規定した線量となる照射時間が経過すると自動的 に線源が遮蔽位置に移動し, 寝台が元の位置まで移動 する. $\gamma$ 線源 ${ }^{60} \mathrm{Co}$ の測定時の線量率は $16 \mathrm{~mm}$ コリ メータで $1.965 \mathrm{~Gy} / \mathrm{min}$.であった。また，線源位置の 変位量は Perfexion 装置の Service mode から 0.001 $\mathrm{mm}$ 単位で設定可能であり, インターロック機構のた め入力值と実測值は $0.025 \mathrm{~mm}$ 以内で一致していた.

\section{1-3 検討方法}

\section{1-3-1＼cjkstart線源位置変位が線量に及ぼす影響}

計測配置を Fig. $4 \mathrm{a}$ に示す。線量計を配置した球形 ファントムは固定ジグを介して寝台に固定した。線量 計は焦点である幾何学的なアイソセン夕座標 $(100$, 100，100）に設置した。コリメータサイズに合わせて， 適切な線量計を選択した。検討では $4,8 \mathrm{~mm} コ リ$ メータの際に, 半導体検出器を使用し, $16 \mathrm{~mm}$ コリ メータの際に，セミフレックス形電離箱を使用した。 照射野は全 192 本の $\gamma$ 線を用い，コリメータの全区域 を同一のコリメータサイズに統一して，3 種類のコリ メータサイズでそれぞれ測定した。 ファントムがアイ ソセンタに到達し、コリメータサイズが選択された後 に, 1 分間測定を連続して 5 回行い, 平均值と標準偏 差を算出した。また，ヒステリシス現象 ${ }^{14)}$ を低減させ るため事前照射 (5 Gy) を行った。線源位置を各コリ メータの中心から $0.1 \mathrm{~mm}$ 間隔で頭尾方向それぞれに 


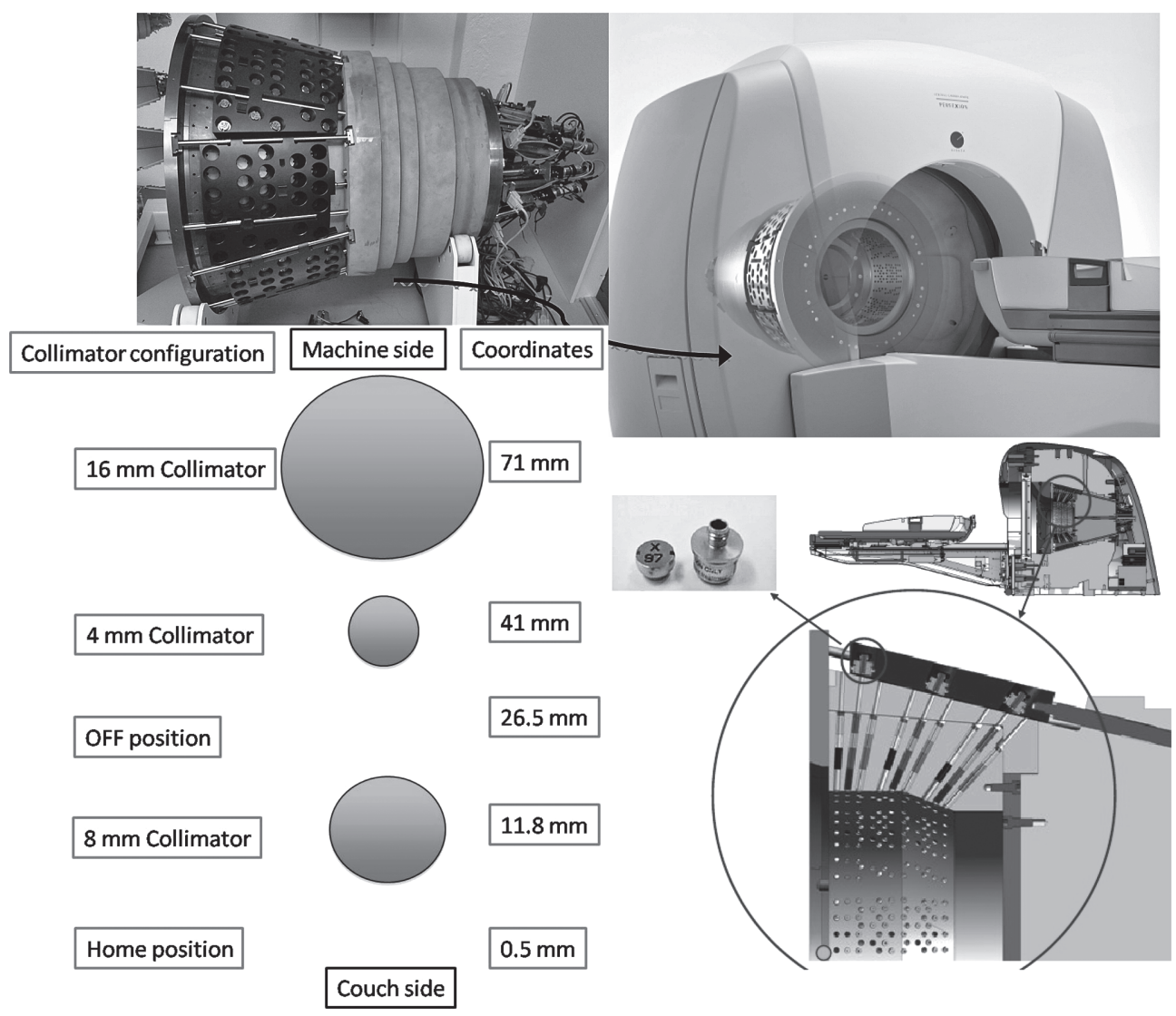

Fig. 2 Collimator body structure (appearance of each collimator configuration and source movement).

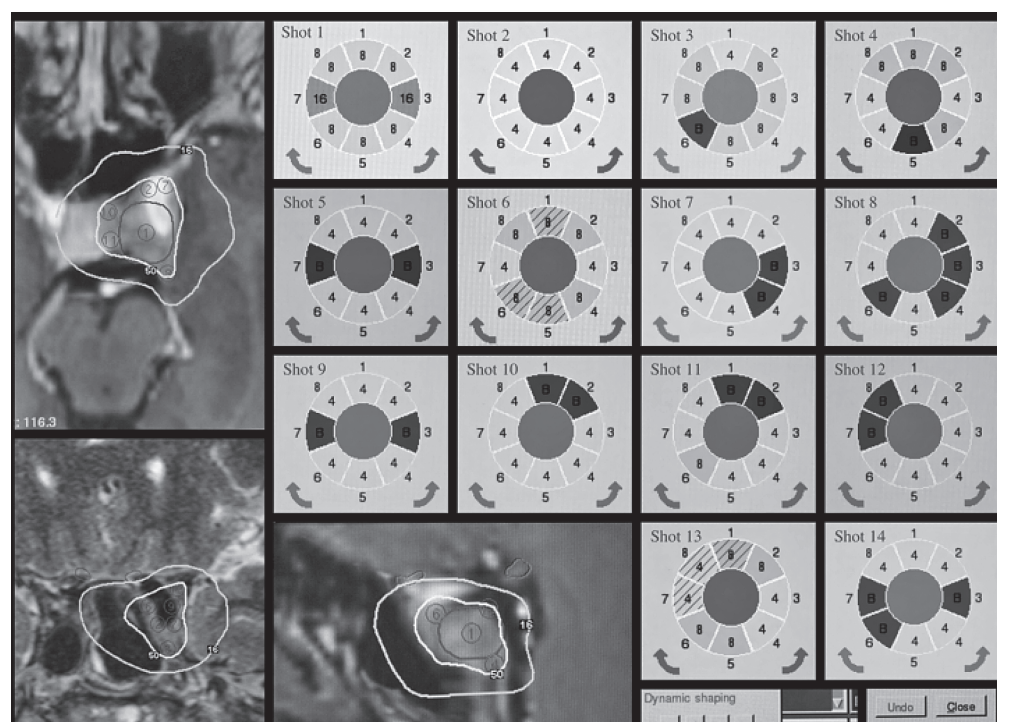

Fig. 3 Representative case of composite shots Collimator size is selected in each section of the collimator.

移動させ，変位させた位置で測定し，線源位置変位が 線量に及ぼす影響を評価した。機械的に, $16 \mathrm{~mm}$ コリ メータではコリメータ中心から頭側 (線源側)に線源を 移動できないため，尾側のみ測定した。

\section{1-3-2＼cjkstart線源位置変位が線量分布に及ぼす影響}

1-3-1 と同様に，球形ファントムを寝台に固定した。 ファントムの中央にはフィルムを挿入したフィルムホ ルダを配置した (Fig. 4b)，ファントムを幾何学的なア イソセンタ座標 $(100 ， 100 ， 100)$ に設置し, フィルムを 

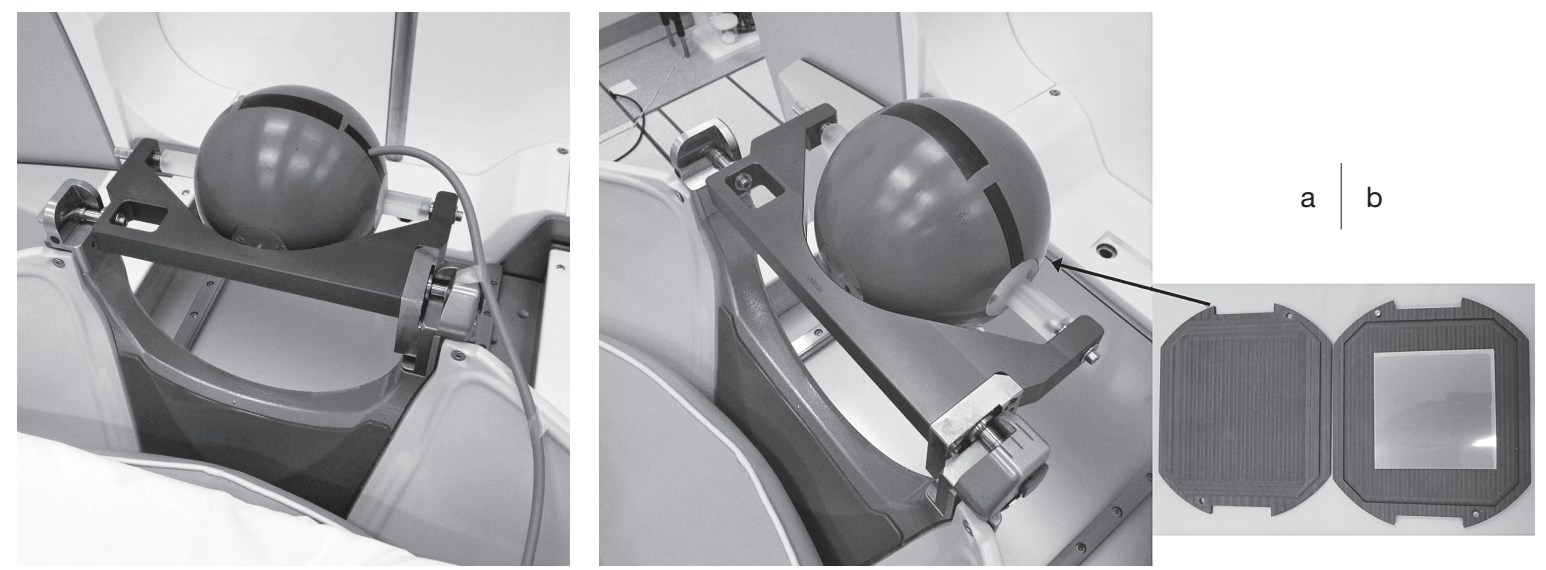

Fig. 4 (a) Appearance of the phantom inserted dosimeter. (b) Appearance of the phantom allocated film holder.
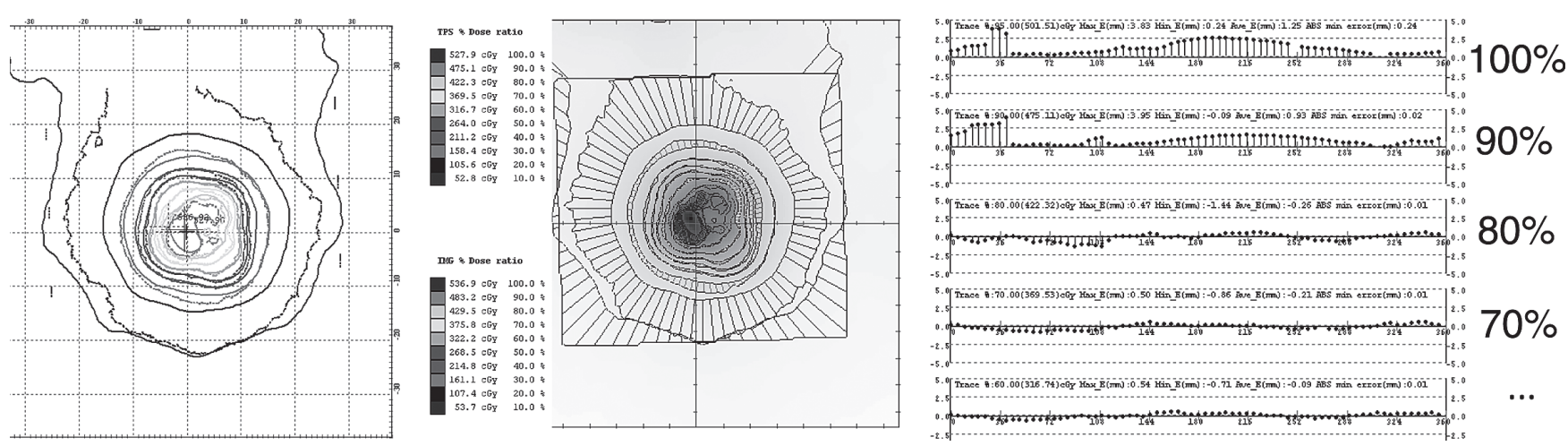

Fig. 5 Representative case of distance-to-agreement analysis.

横断面と冠状断面になるように設置した。照射野はコ リメータの全区域を同一のコリメータサイズに統一し て, 3 種類のコリメータサイズでそれぞれ最大線量 (中 心線量)が $6 \mathrm{~Gy}$ になるよう線量率から照射時間を計 算し，照射した，線源位置を各コリメータの中心から $1 \mathrm{~mm}$ 間隔で $3 \mathrm{~mm}$ まで移動させ, それぞれの位置で 照射し, 線源位置変位が線量分布に及ぼす影響を評価 した．フィルムの濃度変化が一定になるように，照射 から 24 時間経過後, フィルムスキャナを用いて, 赤領 域で読み取り，DD-IMRTで distance to agreement (DTA) 解析を行った ${ }^{15)}$. DTA 解析では 6 度間隔, 60 方向で全周性にわたってコリメータ中心と変位させた 位置間の線量分布を比較するために, 10\%から 90\%等 線量曲線の距離の違いを平均值と最大值で評価した (Fig. 5)。また, フィルム濃度と線量の関係性を評価 するために, 同一のファントムを用いて, $16 \mathrm{~mm} コ リ$ メータで，0，0.5，1，2，3，4，5，6，8 Gy の照射を行 い, 照射後 24 時間経過してからスキャナを用いて, 赤 領域で読み取り, DD-Analysis で線量一濃度 (analogue digital conversion: ADC) 曲線を作成した。

\section{2. 結 果}

\section{2-1＼cjkstart線源位置変位が線量に及ぼす影響}

Fig. 6 にそれぞれ $4 \mathrm{~mm}, 8 \mathrm{~mm}, 16 \mathrm{~mm}$ コリメータ を使用した際の線源位置変位が線量に及ぼす影響を示 した. $4 \mathrm{~mm}$ コリメータでは $0.5 \mathrm{~mm}$ の変位で $5.12 \%$, $1 \mathrm{~mm}$ の変位では 46.29\%の線量低下がみられた。一 方, $8 \mathrm{~mm}$ コリメータでは $0.5 \mathrm{~mm}$ の変位で $0.69 \%, 1$ $\mathrm{mm}$ の変位で $7.04 \%$ の影響であり, $16 \mathrm{~mm}$ コリメータ では $0.5 \mathrm{~mm}$ の変位で $0.21 \%, 1 \mathrm{~mm}$ の変位で $0.89 \%$ の

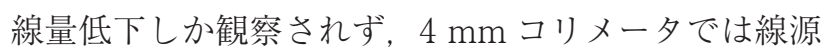
位置変位の線量影響が顕著であった。また，各コリ メータで線源位置変位が増加するほど, 線量が低下す る傾向であった。

\section{2-2 線源位置変位が線量分布に及ぼす影響}

Fig. 7 に線量－濃度変換曲線を示す. Table 1, 2 に それぞれ線源位置変位が横断面, 冠状断面の線量分布 に及ぼす影響をDTA 值で示す。 $1 \mathrm{~mm}$ の変位では全 コリメータの全等線量曲線で DTA 值の平均が $1 \%$ 以 下であり，線量分布に及ぼす影響は少なかった。ま 


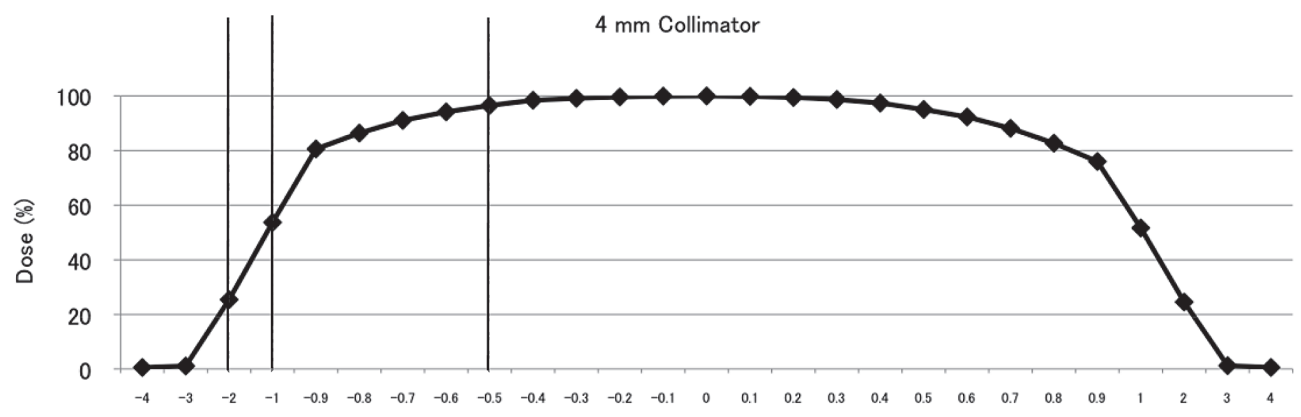

Source discrepancy $(\mathrm{mm})$

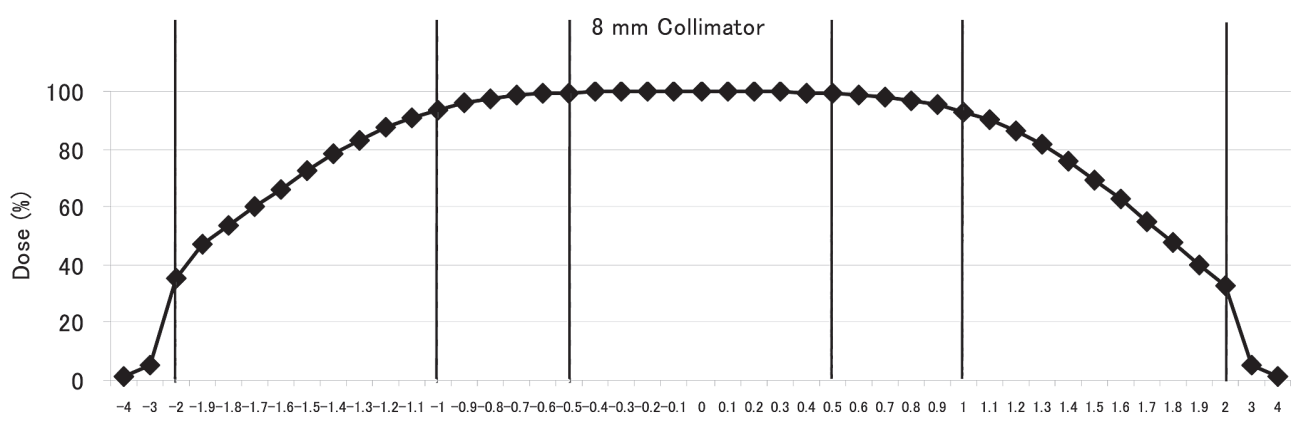

Source discrepancy $(\mathrm{mm})$

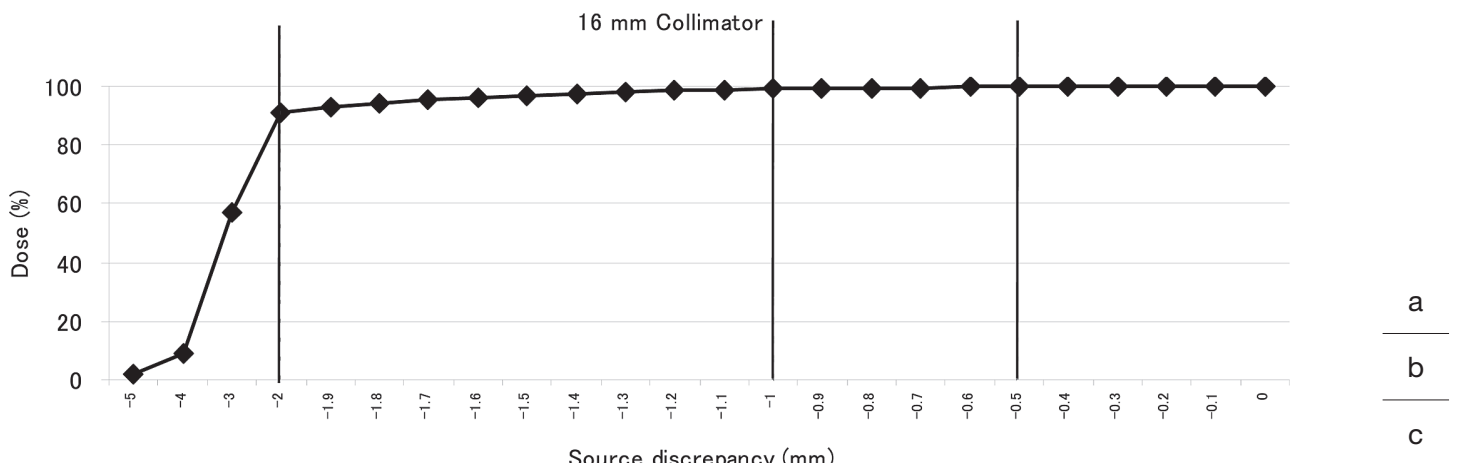

Fig. 6 Effect of source positional discrepancy on dose.

(a) $4 \mathrm{~mm}$ collimator, (b) $8 \mathrm{~mm}$ collimator, (c) $16 \mathrm{~mm}$ collimator.

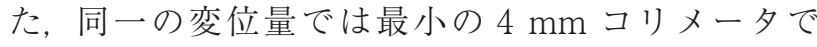
DTA 值が最大で等線量曲線の変化が顕著であった。 全コリメータに共通して, 線源位置変位が増加するほ ど, DTA 值が増加した. また, 冠状断面の変化と比 較して, 横断面の変化のほうが大きい傾向があり, 変 位量が大きいほど両者に差が生じた。Fig. 8 に $16 \mathrm{~mm}$ コリメータで線源を $3 \mathrm{~mm}$ 変位させた際の横断面のプ ロファイルカーブを示す。線源位置を変位させること によって, プロファイルカーブは収縮し, 急峻な線量 勾配を示した。

\section{3. 考 察}

ガンマナイフ治療計画では病巣の位置や形状に合わ せて適切なコリメータサイズを選択し，単一または複
数の楕円形照射野 (ショット)を配置して，フォワード プランニングで線量分布を作成する。病巣にできる限 り線量分布を一致させるために, 複数のショットを使 用する方法が最も簡便な手段であり, 機械性能が従来 モデルから大きく改善したPerfexion ではその傾向が 顕著に現れていることを以前の論文で報告した ${ }^{16)}$. American Association of Physicists in Medicine $\left(\mathrm{AAPM}\right.$ ) report ${ }^{17)}$ ではショット数が増加することに よってPPSの幾何学的な不確かさが増加する可能性 があると報告しているが，われわれの検討の結果から 両者に相関はなく，治療計画はショット数に依存する ことなく，実際に良好に再現可能であると結論づけ た ${ }^{18)}$. しかし, Perfexionの場合, PPSの不確かさに加 えて, 線源移動の不確かさにも注意を払う必要があ 


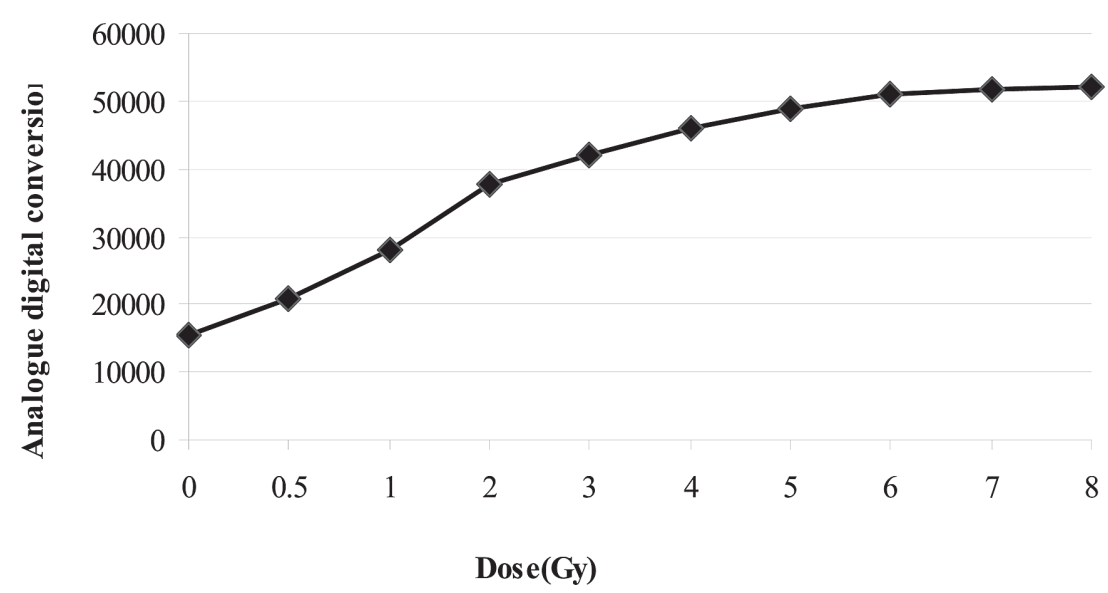

Fig. 7 Absolute dose-analogue digital conversion transformation curve of EBT3 film in the $0-8$ Gy dose range for red channel.

Table 1 Effect of source positional discrepancy on isodose curve of axial plane. Maximum and average values of distance-to-agreement when source position was displaced to 1,2 , and $3 \mathrm{~mm}$ from the center of the collimator

\begin{tabular}{|c|c|c|c|c|c|c|}
\hline \multirow[t]{2}{*}{$4 \mathrm{~mm}$ Collimator } & \multicolumn{2}{|c|}{$1 \mathrm{~mm}$} & \multicolumn{2}{|c|}{$2 \mathrm{~mm}$} & \multicolumn{2}{|c|}{$3 \mathrm{~mm}$} \\
\hline & Max & Average & Max & Average & Max & Average \\
\hline $95 \%$ & 0.45 & 0.3 & 4.7 & 3.61 & 19.85 & 6.34 \\
\hline $90 \%$ & 0.42 & 0.35 & 5.09 & 4.5 & 20.47 & 13.07 \\
\hline $80 \%$ & 0.37 & 0.29 & 5.69 & 3.67 & 24.01 & 14.98 \\
\hline $70 \%$ & 0.17 & 0.22 & 6.14 & 4.63 & 28.69 & 17.02 \\
\hline $60 \%$ & 0.18 & 0.1 & 6.71 & 5.63 & 28.71 & 17.95 \\
\hline $50 \%$ & 0.15 & 0.06 & 7.99 & 6.38 & 26.39 & 18.26 \\
\hline $40 \%$ & 0.4 & 0.29 & 9.78 & 7.79 & 27.96 & 16.11 \\
\hline $30 \%$ & 0.73 & 0.63 & 12.4 & 9.85 & 27.96 & 16.11 \\
\hline $20 \%$ & 1.22 & 1 & 21.42 & 13.69 & 26.54 & 16.79 \\
\hline $10 \%$ & 2.75 & 0.91 & 22.88 & 14.5 & 24.25 & 14.62 \\
\hline \multirow[t]{2}{*}{$8 \mathrm{~mm}$ Collimator } & \multicolumn{2}{|c|}{$1 \mathrm{~mm}$} & \multicolumn{2}{|c|}{$2 \mathrm{~mm}$} & \multicolumn{2}{|c|}{$3 \mathrm{~mm}$} \\
\hline & Max & Average & Max & Average & Max & Average \\
\hline $95 \%$ & 0.83 & 0.66 & 1.84 & 1.62 & 8.65 & 7.24 \\
\hline $90 \%$ & 0.83 & 0.73 & 1.75 & 1.6 & 8.98 & 7.2 \\
\hline $80 \%$ & 0.63 & 0.55 & 1.35 & 1.21 & 9.76 & 7.47 \\
\hline $70 \%$ & 0.58 & 0.47 & 1.07 & 0.85 & 11.33 & 8.06 \\
\hline $60 \%$ & 0.51 & 0.39 & 0.63 & 0.45 & 14.26 & 10.22 \\
\hline $50 \%$ & 0.5 & 0.35 & 0.58 & 0.26 & 18.36 & 13.43 \\
\hline $40 \%$ & 0.34 & 0.15 & 1.59 & 1.03 & 26.11 & 17.48 \\
\hline $30 \%$ & 0.39 & 0.05 & 2.12 & 1.54 & 25.19 & 18.31 \\
\hline $20 \%$ & 0.94 & 0.52 & 4.15 & 2.87 & 23.94 & 17.03 \\
\hline $10 \%$ & 3.06 & 0.93 & 8.2 & 5.63 & 20.4 & 13.78 \\
\hline \multirow[t]{2}{*}{$16 \mathrm{~mm}$ Collimator } & \multicolumn{2}{|c|}{$1 \mathrm{~mm}$} & \multicolumn{2}{|c|}{$2 \mathrm{~mm}$} & \multicolumn{2}{|c|}{$3 \mathrm{~mm}$} \\
\hline & Max & Average & Max & Average & Max & Average \\
\hline $95 \%$ & 2.87 & 0.99 & 3.24 & 2.9 & 4.71 & 4.29 \\
\hline $90 \%$ & 1.71 & 0.82 & 2.6 & 2.41 & 4 & 3.61 \\
\hline $80 \%$ & 1.25 & 0.9 & 1.9 & 1.65 & 3.07 & 2.74 \\
\hline $70 \%$ & 1.27 & 0.93 & 1.74 & 1.42 & 2.54 & 2.19 \\
\hline $60 \%$ & 1.26 & 0.93 & 1.61 & 1.28 & 2.13 & 1.73 \\
\hline $50 \%$ & 1.24 & 0.85 & 1.54 & 1.18 & 1.21 & 0.75 \\
\hline $40 \%$ & 0.83 & 0.4 & 0.94 & 0.41 & 1.61 & 0.62 \\
\hline $30 \%$ & 0.58 & 0.1 & 0.98 & 0.42 & 3.24 & 2.58 \\
\hline $20 \%$ & 1.71 & 0.89 & 2.3 & 1.18 & 5.18 & 3.46 \\
\hline $10 \%$ & 3.07 & 0.83 & 4.06 & 2.46 & 5.67 & 2.29 \\
\hline
\end{tabular}


Table 2 Effect of source positional discrepancy on isodose curve of coronal plane. Maximum and average values of distance-to-agreement when source position was displaced to 1 , 2 , and $3 \mathrm{~mm}$ from the center of the collimator

\begin{tabular}{|c|c|c|c|c|c|c|}
\hline \multirow[t]{2}{*}{$4 \mathrm{~mm}$ Collimator } & \multicolumn{2}{|c|}{$1 \mathrm{~mm}$} & \multicolumn{2}{|c|}{$2 \mathrm{~mm}$} & \multicolumn{2}{|c|}{$3 \mathrm{~mm}$} \\
\hline & Max & Average & Max & Average & Max & Average \\
\hline $95 \%$ & 0.36 & 0.22 & 0.39 & 0.2 & 0.58 & 0.45 \\
\hline $90 \%$ & 0.25 & 0.16 & 0.25 & 0.15 & 0.75 & 0.57 \\
\hline $80 \%$ & 0.21 & 0.09 & 0.2 & 0.09 & 0.86 & 0.8 \\
\hline $70 \%$ & 0.16 & 0.05 & 0.16 & 0.16 & 0.77 & 0.37 \\
\hline $60 \%$ & 0.13 & 0.01 & 0.2 & 0.01 & 0.71 & 0.53 \\
\hline $50 \%$ & 0.18 & 0.04 & 0.31 & 0.04 & 0.71 & 0.49 \\
\hline $40 \%$ & 0.26 & 0.07 & 0.39 & 0.18 & 0.7 & 0.44 \\
\hline $30 \%$ & 0.43 & 0.15 & 0.58 & 0.17 & 0.85 & 0.43 \\
\hline $20 \%$ & 0.65 & 0.19 & 0.83 & 0.23 & 0.86 & 0.39 \\
\hline $10 \%$ & 1.13 & 0.24 & 1.31 & 0.39 & 1.83 & 0.36 \\
\hline \multirow[t]{2}{*}{$8 \mathrm{~mm}$ Collimator } & \multicolumn{2}{|c|}{$1 \mathrm{~mm}$} & \multicolumn{2}{|c|}{$2 \mathrm{~mm}$} & \multicolumn{2}{|c|}{$3 \mathrm{~mm}$} \\
\hline & Max & Average & Max & Average & Max & Average \\
\hline $95 \%$ & 0.46 & 0.19 & 2.14 & 1.41 & 1.86 & 0.77 \\
\hline $90 \%$ & 0.42 & 0.2 & 2 & 1.26 & 2.05 & 1.11 \\
\hline $80 \%$ & 0.36 & 0.21 & 1.76 & 1.15 & 2.18 & 1.28 \\
\hline $70 \%$ & 0.31 & 0.13 & 1.35 & 0.9 & 2.07 & 1.18 \\
\hline $60 \%$ & 0.3 & 0.1 & 1.05 & 0.73 & 1.85 & 1.06 \\
\hline $50 \%$ & 0.25 & 0.04 & 0.82 & 0.61 & 1.66 & 0.97 \\
\hline $40 \%$ & 0.3 & 0.01 & 0.76 & 0.48 & 1.39 & 0.86 \\
\hline $30 \%$ & 0.61 & 0.09 & 0.78 & 0.44 & 1.24 & 0.76 \\
\hline $20 \%$ & 0.89 & 0.19 & 0.95 & 0.32 & 1.5 & 0.61 \\
\hline $10 \%$ & 1.66 & 0.57 & 3.06 & 0.59 & 3.98 & 0.56 \\
\hline \multirow[t]{2}{*}{$16 \mathrm{~mm}$ Collimator } & \multicolumn{2}{|c|}{$1 \mathrm{~mm}$} & \multicolumn{2}{|c|}{$2 \mathrm{~mm}$} & \multicolumn{2}{|c|}{$3 \mathrm{~mm}$} \\
\hline & Max & Average & Max & Average & Max & Average \\
\hline $95 \%$ & 0.85 & 0.43 & 1.38 & 0.7 & 1.5 & 0.53 \\
\hline $90 \%$ & 0.48 & 0.22 & 1.18 & 0.63 & 2.05 & 1.24 \\
\hline $80 \%$ & 0.29 & 0.13 & 0.97 & 0.94 & 2.27 & 1.59 \\
\hline $70 \%$ & 0.24 & 0.11 & 0.78 & 0.46 & 2.31 & 1.57 \\
\hline $60 \%$ & 0.19 & 0.16 & 0.68 & 0.41 & 2.11 & 1.42 \\
\hline $50 \%$ & 0.27 & 0.22 & 0.61 & 0.39 & 1.63 & 1.27 \\
\hline $40 \%$ & 0.37 & 0.35 & 0.75 & 0.38 & 1.88 & 1.09 \\
\hline $30 \%$ & 0.85 & 0.68 & 1 & 0.44 & 2.11 & 1.05 \\
\hline $20 \%$ & 1.33 & 0.25 & 1.8 & 0.53 & 2.47 & 2.31 \\
\hline $10 \%$ & 3.31 & 0.94 & 3.76 & 0.74 & 4.33 & 4.04 \\
\hline
\end{tabular}

る，過去に，自施設でもセク夕動作時の摩擦によって 異音が発生し，照射が正確に行われているか否かを点 検し，問題がないことを確認した。セクタの位置は MLC と同様に 2 種類の機構の異なる装置 (リニアス ケールとエンコーダ)で監視しており，装置のスペッ ク上, $0.01 \mathrm{~mm}$ 以下の単位で位置を認識し, $0.05 \mathrm{~mm}$ を超えるとインターロックが発生し，照射が停止す る。エンコーダは主センサとして用いられ，精度が高 い特徵がある。一方，リニアスケールは精度が低く， 副センサとして用いられるが，壊れやすい。したがっ て，センサの故障は現実的に起こりうることであり， 治療の質を担保するためにもユーザが定期的に線量測 定を行い，PPS およびセクタの動作に異常がないか確
認するべきである，尚，当院では最低でも月に 1 度の 線量測定を行い，測定值から算出した線量率が治療計 画装置で設定されている理論上の線量率と相違がない か確認している.

本検討では，ガンマナイフの極小照射野における測 定を正確に行うために, 線量計の有感体積を考慮し, コリメータサイズに対して適切な線量計を選択した。 また, 検討直前に基準(変位 $0 \mathrm{~mm}$ ) 位置で線量を測定 し，線量計がアイソセン夕に適切に配置されているこ とを確認した，線源位置がコリメータ中心から離れる ほど線量と線量分布に影響することが明らかとなっ た。特に，コリメータサイズが最小の $4 \mathrm{~mm}$ コリメー 夕ではわずか $0.5 \mathrm{~mm}$ の変位で $5 \%$ の線量誤差を生じ 

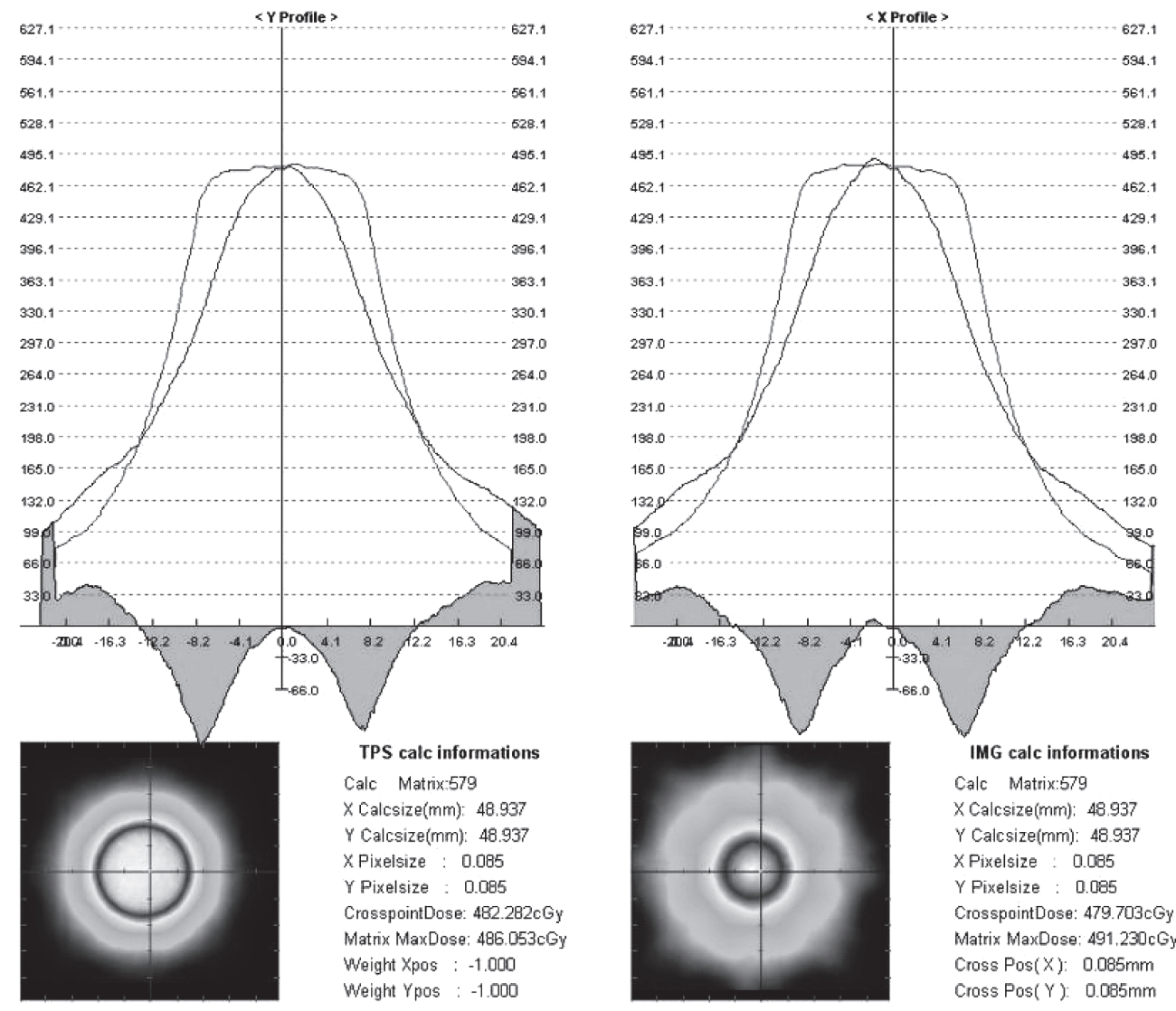

Fig. $8 \mathrm{X}$ and $\mathrm{Y}$ profile curves on axial plane in $16 \mathrm{~mm}$ collimator setting of $3 \mathrm{~mm}$ discrepancy from the center of the collimator.

た.一方, $8 \mathrm{~mm}, 16 \mathrm{~mm}$ コリメータでは $0.5 \mathrm{~mm}$ の変 位でも $0.5 \%$ 以下の線量誤差に過ぎなかった。線量分 布に関しては $1 \mathrm{~mm}$ の変位でも全コリメータサイズで 平均 $1 \mathrm{~mm}$ 以下の線量プロファイルの変化しか観察さ れなかった。したがって，仮に 0.5 から $1 \mathrm{~mm}$ 以下の 線源のわずかな変位が生じた場合, $8 \mathrm{~mm}, 16 \mathrm{~mm}$ コ リメータのみを用いて複数ショットを配置し, 線量分 布を作成している際は線量および線量分布の影響を無 視できる範囲であるが, $4 \mathrm{~mm}$ コリメータを使用する 場合, 線量低下に伴う線量分布の変化が生じ, 臨床的

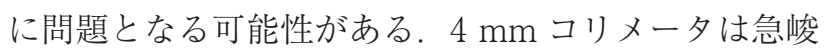
な線量勾配が要求される三叉神経痛や聴神経腫瘍, 下 垂体腺腫など良性腫瘍の治療計画では必要不可欠であ り，その影響は計り知れない.

本研究における線量分布測定では線源位置が変化す ることによって, 同じ照射時間でも最大線量が減少す るため, 解析時に使用する線量 - 濃度曲線の位置 (傾 き)の変化が解析結果に影響したと考えられる。一般 的にガンマナイフ治療計画では線量を $50 \%$ 付近の等 線量曲線に処方し, それ以外の低線量域および高線領 域の線量分布はほとんど考慮していない，測定では最 大線量を $6 \mathrm{~Gy}$ とし，50\%辺縁線量は $3 \mathrm{~Gy}$ となる. 3
Gy 付近は線量 - 濃度曲線の傾きを線形近似可能であ り，解析にほとんど影響していないと考えられる。し かし, 周囲にリスク臓器が近接している場合は 30 か ら 40\%の低線量域を評価することもあるため, 線量勾 配の傾きが解析結果に影響している可能性がある.

今後, ガンマナイフ治療は分割照射 ${ }^{1920)}$, 不均質を 考慮した線量計算アルゴリズム ${ }^{21)}$ などの発展によっ て脳神経外科手術装置から放射線治療装置に役割が変 化する可能性がある。手術装置として品質管理を実施 していない現状を打開するためにもガイドラインの立 案, 整備が進むことが望まれる.

\section{4. 結 語}

本研究ではガンマナイフ Perfexion における線源位 置変位が線量および線量分布に及ぼす影響について検 討した，検討結果より，線源位置がわずかに変位する だけで急激な線量の低下を引き起こすが，線量分布に 対する影響は少ないことが判明した。直線加速器の MLC の位置変位と同様に，ガンマナイフ治療におけ る線源位置変位の影響を把握することは臨床上有益で あり, 特に, 標的に危険臓器が近接している場合, 最 も急峻な線量勾配を作成できる最小サイズの $4 \mathrm{~mm} コ$ 
リメータでは線源位置変位による線量影響は顕著であ

り，定期的に品質管理することが望まれる。
謝 辞

本研究にご協力いただいた，ELEKTA 株式会社の

河合雅彦氏，萩本健二氏，名古屋共立病院名古屋放射

線外科センタースタッフー同に深く感謝致します。

\section{参考文献}

1) Nakazawa H, Komori M, Mori $Y$, et al. Effect of skull contours on dose calculations in Gamma Knife Perfexion stereotactic radiosurgery. J Appl Clin Med Phys 2014; 15(2): 28-38.

2) Lindquist $C$, Paddick I. The Leksell Gamma Knife Perfexion and comparisons with its predecessors. Neurosurgery 2007; 61 (3 Suppl): 130-140, dissucussion 140-141.

3) Régis J, Tamura M, Guillot $C$, et al. Radiosurgery with the world's first fully robotized Leksell Gamma Knife PerfeXion in clinical use: a 200-patient prospective, randomized, controlled comparison with the Gamma Knife 4C. Neurosurgery 2009; 64 (2): 346-355, discussion 355-356.

4) Nakazawa H, Komori M, Oguchi H, et al. Assessment of spatial uncertainty in computed tomography-based Gamma Knife stereotactic radiosurgery process with automated positioning system. Acta Neurochir (Wien) 2014; 156(10): 1929-1935.

5）馬場貞明, 中西雄一, 尾本恵理, 他. ガンマナイフ C 型と B 型の臨床に扔ける比較検討。日放技師会誌 2007; 54 (12): 1511-1515.

6）有路貴樹，上田隆司，木藤哲史，他． Intensity Modulated Radiation Therapy(IMRT)の最適化に㧍ける使用経験と問 題点－頭頸部 IMRT を中心に一。放技学誌 2010; 66(8): 879-884.

7）小野 薰, 中村哲之, 大和真一郎. 他. Dynamic Log File による Dynamic Multileaf Collimator の精度試験. 日放技 学誌 2007; 63(7): 766-773.

8）佐々木幹治, 富永正英, 生島仁史, 他. マルチリーフコリ メータの位置精度が強度変調放射線治療の線量分布に及 ぼす影響。日放技学誌 2011; 67(5): 497-506.

9) 中口裕司, 大野 剛, 荒木不次男, 他. 最新の 80 対マル チリーフコリメータの物理特性. 日放技学誌 2013; 69(7): 778-783.

10) LoSasso T, Chui CS, Ling CC. Physical and dosimetric aspects of a multileaf collimation system used in the dynamic mode for implementing intensity modulated radiotherapy. Med Phys 1998; 25(10): 1919-1927.

11) Okumura M, Obata $Y$, Shimomura $K$, et al. The effect of gantry and collimator angles on leaf limited velocity and position in dynamic multileaf collimator intensity-modulated radiation therapy. Phys Med Biol 2010; 55(11): 3101-3113.

12）日本放射線腫瘍学会 QA 委員会 編。強度変調放射線治療 における物理・技術的ガイドライン 2011 .

13) Nakazawa H, Mori $Y$, Komori M, et al. Simulational study of a dosimetric comparison between a Gamma Knife treatment plan and an intensity-modulated radiotherapy plan for skull base tumors. J Radiat Res 2014; 55(5): 518-526.

14) Ezzell GA, Galvin JM, Low D, et al. Guidance document on delivery, treatment planning, and clinical implementation of IMRT: report of the IMRT Subcommittee of the AAPM Radiation Therapy Committee. Med Phys 2003; 30(8): 20892115.

15）宮沢正則. ガフクロミックフィルムを用いた線量分布測 定法. 日放技学誌 2006; 62(10): 1428-1436.

16）中澤寿人, 内山幸男, 萩原昌宏, 他. コバルト 60 定位手 術的照射装置の違いが治療計画に及ぼす影響. 日放技学 誌 2014; 70(5): 439-444.

17) Snell M, Bova F, Larson D, et al. Stereotactic Radiosurgery, Report of TG42. Med Phys 1995.

18）中澤寿人，内山幸男，小森雅孝，新型コバルト 60 定位手 術的照射装置に抢ける線量分布の検証㧍よび解析. 日放 技学誌 2015; 71(2): 92-98.

19) Ruschin M, Komljenovic PT, Ansell S, et al. Cone beam computed tomography image guidance system for a dedicated intracranial radiosurgery treatment unit. Int J Radiat Oncol Biol Phys 2013; 85(1): 243-250.

20) Higuchi $Y$, Serizawa $T$, Nagano $O$, et al. Three-staged stereotactic radiotherapy without whole brain irradiation for large metastatic brain tumors. Int J Radiat Oncol Biol Phys 2009; 74(5): 1543-1548.

21) Nakazawa H, Komori M, Shibamoto $Y$, et al. Dosimetric comparison of absolute and relative dose distributions between tissue maximum ratio and convolution algorithms for acoustic neurinoma plans in Gamma Knife radiosurgery. Acta Neurochir (Wien) 2014; 156(8): 1483-1489, discussion 1489. 